\title{
ANALISIS PENGARUH LOKASI, HARGA DAN KUALITAS PRODUK TERHADAP KEPUASAN KONSUMEN PADA KONSUMEN HANNA KEBAB DI KEBUMEN
}

\author{
${ }^{1}$ Khussnul Agestina, ${ }^{2}$ Ika Susilowati \\ S1 Manajemen Sekolah Tinggi Ilmu Ekonomi Putra Bangsa Kebumen
}

\begin{abstract}
This study aims to determine the effect of location, price, and product quality on customer satisfaction of Hanna Kebab Kebumen.

The problems raised in this study are the Analysis of the Influence of Location, price, and product quality on customer satisfaction of Hanna Kebab Kebumen, with the aim of knowing how much the influence of Location, Price, and Product Quality on Hanna Kebab Kebumen consumer satisfaction partially or simultaneously

Sample data taken in this study are Hanna Kebab Kebumen consumers, amounting to 100 consumers as respondents. Instruments or data collection tools in this study were using questionnaires / questionnaires.

The data analysis tool used in this study is using multiple linear regression analysis. Data analysis techniques used include qualitative analysis and quantitative analysis consisting of validity test, reliability test, $t$ test, $F$ test, multiple linear regression analysis (Likert scale). ) Data were analyzed with the help of SPSS Release 22 for Windows.

From the results of the proof of the first hypothesis that the location partially has a significant effect on satisfaction. From the results of the second hypothesis that prices partially have a significant effect on satisfaction. From the results of the third hypothesis proving that product quality partially has a significant effect on satisfaction. From the results of the fourth hypothesis Location, Price, and Quality of Products simultaneously have a significant effect on satisfaction.

$R$ Square determination coefficient value obtained 0.246 means that $24.6 \%$ satisfaction is influenced by the location variable, price, and product quality while the remaining $75.4 \%(100 \%-24.6 \%)$ is caused by other variables.
\end{abstract}

Keywords: Location, price, product quality, satisfaction, Multiple Linear Regression Analysis 


\begin{abstract}
ABSTRACK
Penelitian ini bertujuan untuk mengetahui pengaruh lokasi, harga, dan kualitas produk terhadap kepuasan konsumen Hanna Kebab Kebumen. Permasalahan yang diangkat dalam penelitian ini adalah Analisis Pengaruh Lokasi, harga, dan kualitas produk terhadap kepuasan konsumen Hanna Kebab Kebumen, dengan tujuan untuk mengetahui seberapa besar pengaruh Lokasi, Harga, dan Kualitas Produk terhadap Kepuasan konsumen Hanna Kebab Kebumen secara parsial maupun simultan.

Data sampel yang diambil pada penelitian ini yaitu konsumen Hanna Kebab Kebumen yang berjumlah 100 konsumen sebagai responden. Instrumen atau alat pengumpulan data pada penelitian ini adalah menggunakan angket/kuesioner. Alat analisis data yang digunakan pada penelitian ini yaitu menggunakan analisis regresi linier berganda. Teknik analisis data yang digunakan antara lain analisis kualitatif dan analisis kuantitatif yang terdiri dari uji validitas, uji reliabilitas, uji t, uji $\mathrm{F}$, analisis regresi linier berganda (skala likert). Data dianalisis dengan bantuan program SPSS Release 22 for Windows.

Dari hasil hasil pembuktian hipotesis pertama bahwa Lokasi secara parsial mempunyai pengaruh yang signifikan terhadap Kepuasan. Dari hasil hipotesis ke dua bahwa Harga secara parsial mempunyai pengaruh yang signifikan terhadap kepuasan. Dari hasil pembuktian hipotesis ketiga bahwa kualitas produk secara parsial mempunyai pengaruh yang signifikan terhadap kepuasan. Dari hasil hipotesis keempat Lokasi, Harga, dan Kualitas Produk secara simultan mempunyai pengaruh yang signifikan terhadap Kepuasan.

Nilai koefisien determinasi R Square diperoleh 0,246 artinya 24,6\% kepuasan di pengaruhi oleh variabel Lokasi, harga, dan kualitas produk sedangkan sisanya $75,4 \%$ (100\%-24,6\%) disebabkan oleh variabel lain.
\end{abstract}

Kata kunci: Lokasi, harga, kualitas produk, kepuasan, Analisis Regresi Linier Berganda. 


\section{Latar Belakang Masalah}

Kepuasan konsumen adalah tingkat perasaan seseorang setelah membandingkan hasil yang ia rasakan dibandingkan dengan harapannya, (Kotler, 2001:46). Kepuasan atau ketidakpuasan pelanggan merupakan bagian dari pengalaman pelanggan terhadap suatu produk atau jasa yang ditawarkan. Berdasarkan pengalaman yang diperolehnya, Pelanggan akan merasakan puas apabila harapan dari pelanggan dapat terpenuhi. Pelanggan memiliki kecenderungan untuk membangun nilai-nilai tertentu. Nilai tersebut akan memberikan dampak bagi pelanggan untuk melakukan perbandingan terhadap kompetitor dari produk atau jasa yang pernah dirasakannya (Margaretha, 2004). Apabila sebuah perusahaan memberikan produk atau jasanya yang berkualitas baik, maka diharapkan mampu memenuhi harapan pelanggan dan akhirnya mampu memberikan nilai yang maksimal serta menciptakan kepuasan bagi pelanggan dibanding kompetitor-kompetitor yang ada.

Sejak dahulu makanan menempati urutan teratas dalam pemenuhan kebutuhan manusia, sehingga masalah pangan dikategorikan ke dalam kebutuhan primer atau kebutuhan pokok. Manusia tidak dapat melepaskan kebutuhannya untuk makan karena hanya dengan makan manusia dapat melangsungkan hidupnya. Setiap orang dalam menikmati hidangan atau makanan, memiliki cara yang berbeda untuk memenuhinya. Sebagian konsumen ada yang beranggapan dari pada makanmakanan yang mewah serta mahal, lebih baik memilih makanan yang biasa tetapi cukup lezat sesuai dengan selera mereka.

Fenomena ini menjadi peluang bagi para pebisnis yang berorientasi pada usaha kuliner untuk berlomba-lomba mendirikan bisnis usaha makanan untuk memenuhi keinginan konsumen. Masing-masing pengusaha makanan kuliner menawarkan menu dengan ciri khas masing-masing serta menampilkan keunggulan produknya. Setiap pengusaha tentunya mengharapkan agar konsumen puas terhadap produk yang ditawarkan, maka dibutuhkan adanya yang penetapan harga yang kompetitif dibandingkan harga yang ditawarkan pesaing, lokasi yang setrategi mudah dijangkau dan kualitas produk yang bermutu yang mampu memberikan kepuasan kepada pelanggan.

Konsumen sebagai penikmat kuliner tentunya akan mempertimbangkan aspek harga, lokasi, dan kualitas produk yang memuaskan, sehingga setelah konsumen merasa puas karena apa yang diharapkan konsumen dapat terpenuhi. Hana Kebab yang terlatak di depan asrama polisi Kebumen misalnya, sebagai salah satu produk makanan kuliner yang menawarkan berbagai macam variasi produk makanannya dengan kualitas produk dan cita rasa yang bervariasi dan cukup memuaskan. Hana Kebab 
merupakan salah satu usaha kuliner yang memiliki keunggulan dengan banyak pilihan menu yang diinginkan oleh konsumen.

Produk makanan kebab Mas Teguh yang yang terletak di depan asrama polisi Kebumen, saat ini merupakan salah satu makanan yang banyak digemari oleh para konsumen, khususnya pecinta makanan kebab. Mas Teguh pemilik usaha Hana Kebab menjual beberapa variasi makanan dengan cita rasa yang berbeda dengan beberapa makanan kuliner yang lain seperti beberapa pesaingnya Martabak Senayan, martabak unyil dll.

Kondisi tersebut membuat pemilik hana kebab Mas Teguh harus berusaha mengembalikan tingkat kepercayaan dan meningkatkan kembali volume penjualan pada usaha produk makanan Hana Kebab yang dimilikinya. Kualitas produk, harga, dan lokasi sangatlah berkaitan erat dengan kepuasan konsumen.

Berdasarkan pada uraian latar belakang masalah yang terjadi di atas maka dapat diajukan sebuah penelitian dengan judul "Analisis

Pengaruh Lokasi, Harga, dan Kualitas Produk, Terhadap Kepuasan Konsumen, Pada Konsumen Hanna Kebab Di Kebumen".

Berdasarkan uraian latar belakang masalah diatas, maka permasalahan yang akan dikaji pada penelitian ini adalah

1. Bagaimana pengaruh lokasi terhadap kepuasan konsumen hana kebab Kebumen?
2. Bagaimana pengaruh harga terhadap kepuasan konsumen hana kebab Kebumen?

3. Bagaimana pengaruh kualitas produk terhadap kepuasan konsumen hana kebab Kebumen?

4. Bagaimana pengaruh lokasi, harga, dan kualitas produk terhadap kepuasan konsumen hana kebab Kebumen?

Sesuai dengan permasalahan yang telah dirumuskan, tujuan penelitian yang ingin dicapai oleh peneliti adalah sebagai berikut :

1. Mengetahui pengaruh lokasi terhadap kepuasan konsumen hana kebab Kebumen.

2. Mengetahui pengaruh harga terhadap kepuasan konsumen hana kebab Kebumen.

3. Mengetahui pengaruh kualitas produk terhadap kepuasan konsumen hana kebab Kebumen.

4. Mengetahui pengaruh lokasi, harga, dan kualitas produk terhadap kepuasan konsumen hana kebab Kebumen.

Penelitian ini diharapkan dapat mengembangkan ilmu pengetahuan, khususnya Manajemen Pemasaran terutama bagi akademisi yang ingin menganalisis pengaruh lokasi, harga dan kualitas produk, terhadap kepuasan konsumen.

Bagi peneliti, sebagai wahana latihan pengembangan kemampuan dan penerapan teori yang diperoleh dalam perkuliahan.

Sebagai masukan dan pertimbangan bagi pihak pemilik Hanna Kebab dalam mengembangkan strategi menghadapi persaingan, sehingga dapat dijadikan pertimbangan dalam pengembangan 
strategi di masa yang akan datang.

\section{Landasan Teori}

Kepuasan Konsumen

Kepuasan konsumen adalah tingkat perasaan seseorang setelah membandingkan hasil yang ia rasakan dibandingkan dengan harapannya, ( Kotler, 2001 : 46 ). Menurut Philip Kotler (1997: 36), kepuasan konsumen adalah perasaan senang atau kecewa seseorang yang berasal dari perbandingan antara kesannya terhadap kinerja (hasil) suatu produk yang diharapkan.

\section{Kinerja}

Indikator yang akan digunakan mengacu pada penelitian sebelumnya yang dilakukan oleh selnes (1993), Goodman (1995) dan Geykens (1999). Selanjutnya beberapa indikator yang digunakan untuk mengukur variabel kepuasan pelanggan adalah :

1. Rasa senang

Rasa senang menunjukan sejauh mana para pelanggan tersebut merasa senang dengan pengalaman transaksinya.

2. Kepuasan terhadap layanan

Kepuasan terhadap layanan menunjukan sejauh mana para pelanggan merasa puas dengan pelayanan transaksinya.

3. Kepuasan terhadap sistem pelayanan Kepuasan terhadap sistem pelayanan menunjukan sejauh mana kecepatan dan kemudahan sistem transaksi yang disediakan mampu memberikan kepuasan kepada pelanggannya.
4. Kepuasan financial

Kepuasan financial adalh kepuasan pelanggan atau konsumen secara financial meliputi biaya-biaya yang dikeluarkan selama menggunakan jasa pelayanan tersebut.

\section{Lokasi}

Lokasi adalah posisi suatu tempat, benda, peristiwa dipermukaan bumi dalam hubungannya dengan tempat, benda, peristiwa lain. (Maryani, 2009; 16). Komponen lokasi terdiri atas arah dan jarak. Arah menunjukkan posisi suatu tempat dibandingkan dengan tempat lain, sedangkan jarak adalah ukurannya jauh atau dekatnya dua benda atau gejala tersebut. Arah suatu tempat bersifat relatif, demikian pula dengan jarak relatif.Arah dan jarak menentukan intensitas hubungan dua tempat.

Lokasi dapat didefinisikan sebagai tempat bagi perusahaan untuk melaksanakan kegiatan atau usaha sehari-hari.Indikator- indikator dari variabel ini adalah (Tjiptono, 2006):

Akses, yaitu lokasi yang dilalui mudah dijangkau sarana transportasi umum.

1. Visibilitas, yaitu lokasi atau tempat yang dapat dilihat dengan jelas dari jarak pandang normal.

2. Lalu lintas, menyangkut dua pertimbangan utama, yaitu:

a. Banyak orang yang berlalu lalang bisa memberikan peluang besar terjadinya impulse buying, yaitu keputusan pembelian yang sering terjadi spontan atau tanpa 
perencanaan.

b. Kepadatan dan kemacetan lalu lintas bisa juga menjadi hambatan.

3. Tempat parkir yang luas, nyaman dan aman.

4. Ekspansi, yaitu tersedia tempat yang cukup luas untuk perluasan usaha dikemudian hari.

5. Lingkungan, yaitu daerah sekitar yang mendukung jasa yang ditawarkan.

6. Kompetisi, yaitu lokasi pesaing, dalam menentukan lokasi sebuah usaha perlu dipertimbangkan apakah di jalan atau daerah tersebut telah terdapatbanyak usaha yang sejenis atau tidak.

7. Peraturan Pemerintah yang berisi ketentuan untuk mengatur lokasi dari sebuah usaha-usaha tertentu, misalnya bengkel kendaraan bermotor dilarang berlokasi yang terlalu berdekatan dengan tempat ibadah.

\section{Harga}

Menurut Kotler \& Amstrong
(2006: 48) harga merupakan
sejumlah uang yang dibebankan atas
suatu produk atau jasa atau jumlah
dari nilai yang ditukar konsumen
atas manfaat-manfaat karena
memiliki atau menggunakan produk
atau jasa tersebut.
Indikator yang
mencerminkan harga menurut
(Stanton, 1998) yaitu :

1. Keterjangkauan harga

2. Kesesuaian harga dengan kualitas produk

3. Daya saing harga

4. Kesesuaian harga dengan manfaat

\section{Kualitas Produk}

Kualitas Produk (Product Quality) adalah kemampuan suatu produk untuk melaksanakan fungsinya meliputi, daya tahan keandalan, ketepatan kemudahan operasi dan perbaikan, serta atribut bernilai lainnya. Untuk meningkatkan kualitas produk perusahaan dapat menerapkan program "Total

Quality Manajemen TQM). Selain mengurangi kerusakan produk, tujuan produk kualitas total adalah untuk meningkatkan nilai pelanggan, Kotler dan Amstrong (2001:345). Sedangkan menurut Lovelock dalam Tjiptono (2006:229) mendefinisikan kualitas sebagai tingkat mutu yang diharapkan dan pengendalian keragaman dalam mencapai mutu tersebut untuk memenuhi kebutuhan konsumen.

Kualitas memiliki beberapa dimensi, paling tidak terdapat enam dimensi dari kualitas produk yang perlu diperhatikan oleh setiap produsen yang ingin mengejar kepuasan pelanggan terhadap kualitas produk (Irawan, 2003:45). Dari dimensi tersebut maka dapat diambil sebagai indikator yaitu :

1. Performance (kinerja)

2. Reliability (kehandalan)

3. Feature (fitur)

4. Durability (keawetan atau daya tahan)

5. Conformance (kesesuaian) 
(Design (desain) Kerangka Teoritis

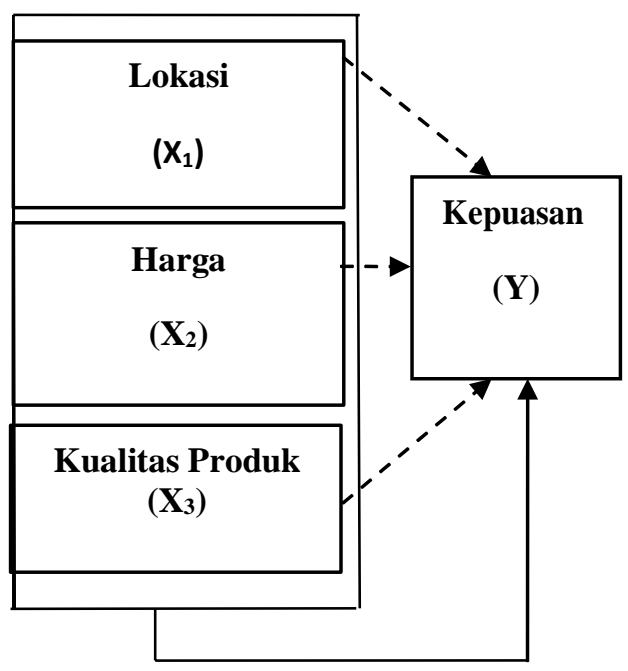

Keterangan:

$----\rightarrow$ : hubungan secara parsial : hubungan secara simultan

\section{Hipotesis}

Berdasarkan uraian diatas maka

hipotesi pada penelitian ini :

H1 : Lokasi berpengaruh signifikan terhadap kepuasan konsumen Hanna Kebab Kebumen.

H2 : Harga berpengaruh signifikan terhadap kepuasan konsumen Hanna Kebab Kebumen.

H3 : Kualitas produk berpengaruh signifikan terhadap kepuasan konsumen Hanna Kebab Kebumen.

H4 : Lokasi, harga, kualitas produk secara simultan berpengaruh signifikan terhadap kepuasan konsumen Hanna Kebab Kebumen.

\section{Metode Penelitian}

\section{Populasi dan Sampel}

Populasi adalah wilayah

generalisasi yang terdiri atas obyek atau subyek yang mempunyai kualitas dan karakteristik tertentu yang ditetapkan oleh peneliti untuk dipelajari dan kemudian ditarik kesimpulannya (Sugiyono,

2010:61). Dalam penelitian ini, yang akan menjadi populasinya konsumen Hanna Kebab Kebumen.

Dalam suatu penelitian, peneliti tidak perlu meneliti semua populasi karena akan memerlukan waktu, biaya dan tenaga besar. Menurut Sugiyono (2010) sampel adalah bagian dari jumlah dan karakteristik yang dimiliki populasi tersebut. Apa yang dipelajari dari sampel itu, kesimpulannya akan dapat diberlakukan untuk populasi. Untuk itu, sampel yang diambil dari populasi harus betul-betul representative (mewakili).

Sampel yang diambil dalam penelitian ini adalah konsumen Hanna Kebab Kebumen.

Jenis dan Sumber Data Data .

1. Jenis Data

a. Data kualitatif, bersifat tidak terstruktur, dikumpulkan dengan menggunakan

metode wawancara, diskusi grup terfokus dan teknik proyeksi.

b. Data kuantitatif, bersifat terstruktur yang memungkinkan peneliti mengubah data semula menjadi data berwujud angka. Data dikumpulkan dengan metode survey atau kuesioner, observasi dan eksperimen.

2. Sumber Data

a. Data Primer adalah data asli yang peneliti dapatkan langsung dari responden.

b. Data Sekunder adalah data yang diperoleh melalui studi kepustakaan, literatur, arsip, dokumen, peraturan dan kebijakan.

\section{Teknik Pengumpulan Data}


Pengumpulan data yang dimaksud untuk memperoleh bahan-bahan yang relevan dan akurat melalui :

a. Observasi yaitu dengan melakukan pengamatan secara langsung pada obyek penelitian.

b. Kuesioner yaitu dengan membuat sejumlah daftar pertanyaan yang berhubungan dengan masalah yang diteliti dan diajukan kepada responden. Jawaban setiap item instrument menggunakan skala likert mempunyai gradasi dari sengat positif sampai sangat negatif, Sugiyono,( $2008: 143$ ).

1. Sangat Setuju skor $=4$

2. Setuju skor $=3$

3. Tidak Setujuskor $=24$.

4. Sangat Tidak Setuju skor $=1$

c. Studi Pustaka, yaitu dengan mengambil teori-teori yang ada pada literatur yang berhubungan dengan masalah yang diteliti.

\section{Teknik Analisis Data}

Dalam perhitungan pengolahan data regresi linier berganda pereliti mempergunakan alat bantu yang berupa program aplikasi komputer yaitu SPSS for windows versi 23

\section{Hasil Analisis Dan Pembahasan}

Regresi Linier Berganda

Berdasarkan hasil dari perhitungan dengan menggunakan bantuan program SPSS maka diketahui hasil uji t regresi linier berganda adalah sebagai berikut :

$\mathrm{Y}=2,109+0,116 \mathrm{X}_{1}+0,296 \mathrm{X}_{2}+0,220 \mathrm{X}_{3}+€_{1}$

Konstanta (a) = 2,109

Artinya apabila variabel lokasi, harga, dan kualitas produk dianggap konstan maka kepuasan sebesar 2.109

1. Variabel independen a. $\mathrm{b} 1=0,116$

Koefisien regresi untuk variabel lokasi $\left(\mathrm{X}_{1}\right)$ sebesar 0,116, artinya jika lokasi meningkat satu satuan, maka kepuasan (Y) akan meningkat sebesar 0,116 satuan.

b. $\mathrm{b} 2=0,296$

Koefisien regresi untuk variabel harga $\left(\mathrm{X}_{2}\right)$ sebesar 0,296, artinya jika harga meningkat satu satuan, maka kepuasan (Y) akan meningkat sebesar 0,296 satuan

c. b3 $=0,220$

Koefisien regresi untuk variabel kualias produk $\left(\mathrm{X}_{3}\right)$ sebesar 0,220, artinya jika kualitas produk meningkat satu satuan, maka kepuasan (Y) akan meningkat sebesar 0,220 satuan

\section{Uji Hipotesis}

a. Pengaruh Lokasi terhadap Kepuasan Berdasarkan analisis untuk variabel lokasi mempunyai pengaruh yang signifikan terhadap Kepuasan, karena

nilai $t_{\text {hitung }}$ sebesar 2,075> r tabel

sebesar 1,984. Besarnya pengaruh lokasi terhadap Kepuasan 0,116 atau 11,6\%. Hal ini berarti semakin baik lokasi dalam sebuah wirausaha maka semakin baik juga kepuasan konsumen, artinya bahwa peran lokasi berpengaruh terhadap kepuasan konsumen.

b. Penngaruh Harga terhadap Kepuasan Berdasarkan analisis untuk variabel harga 


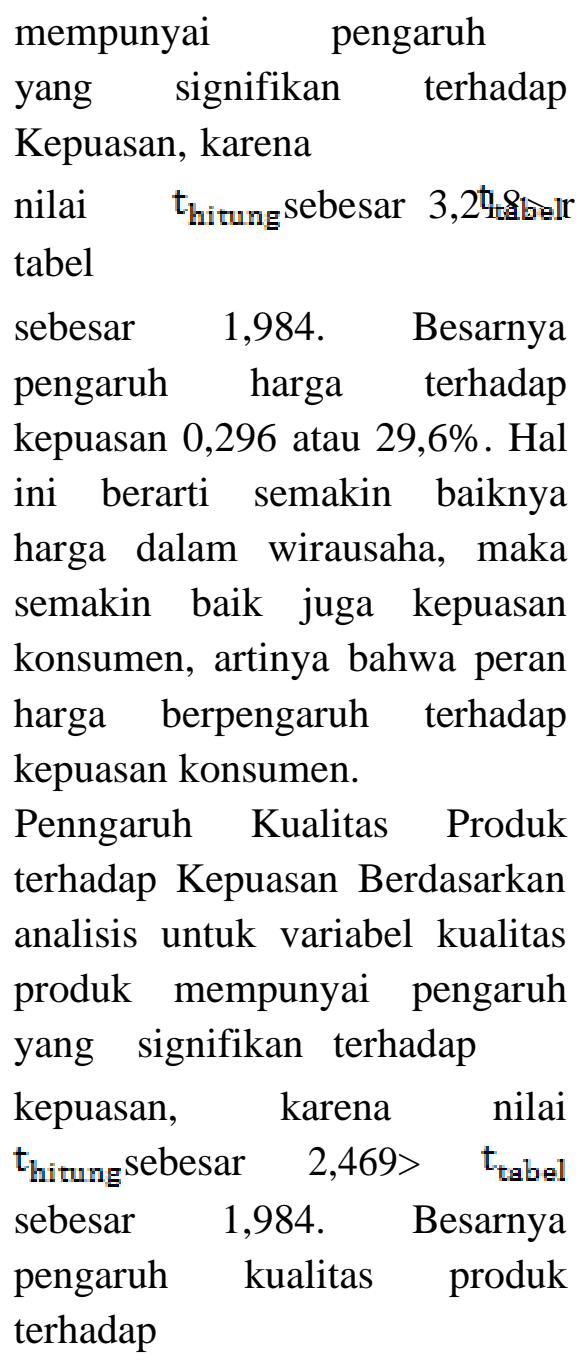

$\left(\mathrm{X}_{3}\right)$ berpengaruh signifikan terhadap kepuasan $(\mathrm{Y})$ secara simultan

\section{Koefisien Determinasi}

Nilai koefisien determinasi $\mathrm{R}$ Square diperoleh 0,246 artinya 24,6\% kepuasan di pengaruhi oleh variabel lokasi, harga, dan kualitas produk, sedangkan sisanya $75,4 \%$ (100\%-24,6\%) disebabkan oleh variabel lain yang tidak ada dalam penelitian ini.

\section{KESIMPULAN DAN SARAN Kesimpulan}

1. Lokasi mempunyai pengaruh yang signnifikan terhadap kepuasan konsumen pada Hanna Kebab Kebumen. Artinya peran lokasi dalam penelitian ini sangat berpengaruh terhadap kepuasan konsuemen pada Hanna Kebab, dengan dibuktikannya hasil diatas, bahwa lokasi yang baik akan berdampak pada kepuasan konsumen pada Hanna Kebab Kebumen, begitu juga sebaliknya lokasi yang kurang baik akan berakibat pada penurunan tingkat kepuasan konsumen.

2. Harga mempunyai pengaruh yang signnifikan terhadap kepuaan konsumen pada Hanna Kebab. Harga disini yaitu harga yang terjangkau, harga yang sesuai dengan yang didapatkan. Artinya peran harga dalam penelitian ini sangat berpengaruh terhadap kepuasan konsumen pada Hanna Kebab, dengan dibuktikannya hasil diatas, bahwa harga yang terjangkau akan berdampak pada kepuasan konsumen pada Hanna Kebab begitu juga sebaliknya harga yang mahal akan berakibat pada penurunan tingkat kepuasan konsumen.

3. Kepuasan 0,220 atau 20,0\%. Hal ini berarti semakin baik kualitas produk dalam sebuah wirausaha, maka semakin baik juga tingkat kepuasan konsumen, artinya bahwa peran kualitas produk berpengaruh terhadap kepuasan

4. Berdasarkan analisis diperoleh $F_{\text {hitung }}$

sebesar 10,456 dengan

tingkat signifikansi $\quad 0.000$, karena probabilitas 0.000 jauh lebih kecil dari 0,050, maka bisa 
dikatakan bahwa variabel lokasi

(X ), harga (X ), dan kualitas produk

3. Kualitas Produk mempunyai pengaruh yang signnifikan terhadap kepuasan konsumen pada Hanna Kebab. Artinya peran kualitas produk dalam penelitian ini sangat berpengaruh terhadap kepuasan konsumen pada Hanna Kebab Kebumen, dengan dibuktikannya hasil diatas, bahwa kualitas produk yang baik akan berdampak pada kepuasan konsumen Hanna Kebab Kebumen, begitu juga sebaliknya kualitas produk yang kurang baik akan berakibat pada penurunan tingkat kepuasan konsumen.

4. Lokasi, harga, dan kualitas produk mempunyai pengaruh terhadap kepuasan konsumen Hanna Kebab Kebumen. Artinya peran ketiga variabel tersebut dalam penelitian ini sangat penting untuk meningkatkan kepuasan konsumen Hanna Kebab Kebumen.

5. Berdasarkan hasil analisis variabel lokasi, harga, dan kualitas produk mempunyai pengaruh yang signifikan terhadap kepuasan konsumen pada Hanna Kebab Kebumen. Variabel yang berpengaruh paling dominan terhadap kepuasan konsumen yaitu variabel harga, variabel yang berpengaruh kedua yaitu kualitas produk dan variabel yang berpengaruh paling kecil yaitu lokasi.

\section{Saran}

a. Bagi manajemen Hanna Kebab Kebumen diharap untuk memperhatikan faktor lokasi pada Hanna Kebab Kebumen, karena faktor lokasi yang baik dapat meningkatkan kepuasan konsumen Hanna Kebab Kebumen. Lokasi yang baik yang strategis, akses parkir nyaman dan mudah akan meningkatkan kepuasan konsumen seperti lokasi yang setrategis lokasi yang dilalui mudah dijangkau sarana transportasi umum, lokasi atau tempat yang dapat dilihat dengan jelas dari jarak pandang normal, Tempat parkir yang luas, nyaman dan aman, tersedia tempat yang cukup luas untuk perluasan usaha dikemudian hari.

Bagi manajemen Hanna Kebab Kebumen diharap untuk memperhatikan faktor harga, karena faktor harga yang baik dapat meningkatkan kepuasan konsumen pada Hanna Kebab Kebumen. Harga yang terjangkau, harga yang sesuai dengan apa yang didapatkan oleh konsumen dapat meningkatkan kepuasan konsumen pada Hanna Kebab Kebumen seperti keterjangkauan harga, keseusaian harga dengan kualitas produk, kesesuaian harga dengan manfaat.

b. Bagi Manajemen Hanna Kebab Kebumen diharap untuk memperhatikan faktor kualitas produk pada Hanna Kebab 
Kebumen, karena faktor kualitas produk yang baik dapat meningkatkan kepuasan konsumen karyawan pada Hanna Kebab Kebumen. Kualitas produk yang baik akan meningkatkan kepuasan konsumen, seperti rasa produk yang enak, bentuk produk yang menarik, ketahanan produk yang lama kinerja atau fungsi utama dari produk, inovasi produk, daya tahan produk, mutu produk, desaign produk.

c. Bagi peneliti selanjutnya masih banyak kemungkinan setelah penelitian ini untuk meneliti variabel-variabel lain diluar variabel lokasi, harga, dan kualitas produk yang belum termasuk dalam penelitian ini yang mempunyai pengaruh terhadap kepuasan konsumen, karena R Square diperoleh 0,246 artinya $24,6 \% \quad$ kepuasan konsumen di pengaruhi oleh variabel lokasi, harga, dan kualitas produk, sedangkan sisanya $75,4 \%(100 \%-24,6 \%)$ disebabkan oleh variabel lain yang tidak ada dalam penelitian ini.

d. Berdasarkan dari hasil questioner jawaban responden dan di uji regresi hasil paling dominan atau paling besar mempengaruhi kepuasan konsumen yaitu variabel harga dan hasil paling kecil lokasi, pihak pemilik Hanna Kebab disarankan untuk lebih memperhatikan tentang harga karena harga dalam penelitian merupakan hasil yang paling dominan.

\section{DAFTAR PUSTAKA}

Agnes Niken Puspita sari. 2011.Analisis Pengaruh Kualitas Produk Dan Kualitas Layanan Tehadap Kepuasan Pelanggan untuk Mendorong Minat Beli Ulang (Studi Pada Pengguna Nokia di Semarang). Skripsi Sarjana Semarang: Fakultas Ekonomi Universitas Diponegoro.

AkhmadFauji. 2012.Analisis

Pengaruh Customer

Relationship Management (CRM) Terhadap Nilai Pelanggan dalam

Meningkatkan Kepuasan dan Loyalitas Pelanggan Telkomsel Kebumen. Skripsi Sarjana (Tidak dipublikasikan ). Kebumen: STIE Putra Bangsa.

BilsonSimamora. 2004. RisetPemasaran: Falsafah, Teori dan Aplikasi. Jakarta: Gramedia.

Indra Firdiyansyah 2017, Pengaruh kualitas pelayanan, harga, dan lokasi terhadap kepuasan pelanggan pada warung gubrak kepri Mall kota Batam

Jonathan Sarwono, 2007. Regresi Linier Berganda Untuk Riset Bisnis dengan SPSS.

Kotler, Philip. 1988. Manajemen pemasaran: Analisis Perencanaan, Implementasi dan Pengendalian. Edisi 6.Jilid 2. Jakarta: Erlangga.

Kotler, Philip dan Kevin Lane Keller. 2007. Manajemen Pemasaran. Edisi 12. Jilid 2. Jakarta: 
Indeks.

Nasution,M.N. 2004. Manajemen JasaTerpadu. Jakarta:Ghalia Indonesia.

Novel.2006, Analisis Pengaruh Kualitas Layanan, terhadap Kepuasan Pembeli dan Loyalitas Pembeli dalam Meningkatkan Minata Beli Ulang (Studi Pada Pengisisan Bahan Bakar Umum (SPBU) Jalan Raya Kudus Demak KM.5).

OldiArdhana. 2010. Analisis pengaruh Kualitas Layanan, Harga, dan Lokasi terhadap Kepuasan Konsumen. Skripsi Sarjana Semarang: Universitas Diponegoro.

Rahadian Ali Oetomo. 2012.Analisis Pengaruh Keragaman Menu, Persepsi Harga, dan Lokasi terhadap Minat Beli Ulang (Studi Pada Restoran Warung Taman Singosari Semarang). Skripsi Sarjana Semarang: Universitas Diponegoro.

Rayi Endah 2008. pengaruh kualitas layanan (X1), kualitas produk (X2) dan harga (X3) terhadap kepuasan pelanggan $(Y)$ restoran Warung Taman Singosari Semarang

Setiadi, Nugroho J. 2010. Perilaku Konsumen: Perspektif Kontemporer pada Motif, Tujuan, dan Keinginan Konsumen. Edisi Revisi. Jakarta: Kencana.

Swastha, Basu. 2002. Manajemen
Pemasaran Analisis Perilaku

Konsumen. Yogyakarta:

Liberty.

Tjiptono, Fandy. 2007. Pemasaran Jasa.

Jakarta: Bayu Media Publishing. YuzzaBayhaqi.2006. Analisis Pengaruh Kualitas Layanan, dan Keunggulan Produk Terhadap Kepuasan Pelanggan dan Dampaknya pada Minat Beli Ulang. Skripsi Sarjana Universitas Diponegoro. 